\title{
Modeling Technical Efficiency With Production Risk: A breakdown of Kebbi State rice farms
}

\author{
Abubakar H. Kara ${ }^{* 1}$, Mad N. Shamsudin'2 ${ }^{2}$ Zainalabidin Muhamed ${ }^{3}$, Ismail Abd Latif ${ }^{3}$, Kelly WK.Seng ${ }^{3}$ and \\ Edon Aboki ${ }^{3}$
}

${ }^{1}$ Abubakar H. Kara, Department of Agricultural economics and extension, Faculty of Agriculture, Taraba State University PMB 1167 Jalingo, Taraba State, Nigeria.

2Mad N.Shamsudin, Department of Agribusiness and Bioresource Economics Faculty of Agriculture, Universiti Putra Malaysia, 43400 UPM Serdang, Selangor Malaysia.

3Zainalabidin Muhamed, Department of Agribusiness and Bioresource Economics, Faculty of Agriculture Universiti Putra Malaysia, 43400 UPM Serdang, Selangor Malaysia.

3Ismail Abd Latif, Department of Agribusiness and Bioresource Economics, Faculty of Agriculture Universiti Putra Malaysia, 43400 UPM Serdang, Selangor Malaysia.

${ }^{3}$ Kelly WK Seng, Department of Agribusiness and Bioresource Economics, Faculty of Agriculture Universiti Putra Malaysia, 43400 UPM Serdang, Selangor Malaysia.

${ }^{3}$ Edon Aboki, Department of Agricultural Economics and Extension, Faculty of Agriculture, Taraba State University PMB 1167 Jalingo, Taraba State, Nigeria

Correspondence Author: Abubakar H. Kara, Abubakar H. Kara, Department of Agricultural economics and extension, Faculty of Agriculture, Taraba State University PMB 1167 Jalingo, Taraba State, Nigeria

Email:

Received date: 20 May 2019, Accepted date: 20 July 2019, Online date: 28 July 2019

Copyright: (C) 2019 Abubakar H. Kara et al., This is an open-access article distributed under the terms of the Creative Commons Attribution License, which permits unrestricted use, distribution, and reproduction in any medium, provided the original author and source are cre dited.

\begin{abstract}
This article deals with modeling technical efficiency with production risk using surveyed data of 398 rice farms in Kebbi State, Nigeria. Stochastic frontier production structure with adaptable risk stipulation was utilized to determine the efficiency level of farmers, production risk associated with input use and avenues of inefficiency. Maximum likelihood estimates of the specified procedure proved that technical efficiency of the producers deviate between $16.1 \%$ and $\mathbf{9 7 . 8 \%}$ with a mean of $\mathbf{8 2 . 1 \%}$. This implies on average $17.9 \%$ rice end product is forfeited because of unskillfulness resulting from a lack of efficiency and production risk in input used. Estimates of risk function revealed fertilizer and labour as risk reducing factors while seed and agrochemicals are risk are risk increasing. Similarly, estimates of inefficiency function showed that education level and extension contact were the factors that significantly decreased technical inefficiency of the respondents in the investigation region while household size was found to increase their technical inefficiency substantially. The examination concluded that on average, rice production in the study area has been in fact wasteful $(0.821)$ and advocates that farmers' should use more of seed and agrochemicals to mitigate production risk in input use. Government should increase farmers access to education and frequent augmentation services. Finally, farmers should ensure the proper use of their family in farming activities in order to reduce inefficiency.
\end{abstract}

Keywords: technical efficiency; production risk; maximum likelihood estimates; stochastic Frontier production

\section{INTRODUCTION}

Over the years, the Nigerian rice segment is producing below the demand of its populace, bringing a vast difference between rice demand and its availability. Accessible insight demonstrated that in 2015, Nigeria produced only 2.3 million tons of rice, while the demand for consumption is around 6.3 million tons [1]. This infers that Nigeria is just 36.5 percent independent in rice generation. The force originating from the requirement for rice contrast with the amount of the item accessible for use appears in the ceaseless increment in the expenses of the commodity along these line has huge relative implications for sustenance security and monetary improvement of the Nigerian economy. For instance, Nigeria is spending approximately US $\$ 300$ million on annual importation of rice [2]. Import policy has discouraged domestic production, increase the level of joblessness and neediness [3]. Successive government administration in Nigeria committed considerable resources in research and development in an attempt to 
address agriculture productivity and market failure issues, however, smallholder farmers are still defined with low harvest yield, limited open door for credit and advice from rural specialists, poor handling and storage facilities and absence of ideal information about market situation bringing high exchange costs related with inputs and output market commitment [4, 5]. In 2015, a renewed effort was made by the government through a partnership model between smallholder farmers and large scale processor. This approach arranges farmers in teams, offer a monetary connection between the farmers and large scale processor to increase rice output and some targeted commodities, this will as well substantially increase the capacity usage of the processors [3].

Agricultural production is defined with risk and uncertainty arising from the incident of pest and disease, weeds, variability in the costs of inputs and output, climate changes among others; these acknowledge final yield to meet a predefined financial target to be unsure. Output or yield is frequently influenced by the use of a given set of input factor and environmental factors. The variability in yield because of particular input choice is the risk related with the input use [6, 7]. Along these lines, a risk opposed farmer would like to utilize to a greater extent of risk decreasing factor than a risk-neutral farmer [8]. Rice cultivation in Kebbi State is presumed to be operating in a condition characterized by risk and uncertainty.

Although, many scholars have looked at variability in rice output caused by an adjustment in a given set of input factors and environmental factors, however, this study incorporates input allotment decision of farmers as a source of variation in rice output. Thus, the study intends to estimate the level of technical efficiency, production risk related to input use and determine the factors affecting technical inefficiency of the farmers. This will give an unbiased estimate of technical proficiency for policy purpose.

\section{MATERIALS AND METHODS}

\subsection{Study Area}

Kebbi State is situated in North-western Nigeria with its capital in Birnin Kebbi. It comprised of twenty-one Local Government Area (LGA) (Figure 1) and four Agricultural Development zones to be specific; Zone I (Birnin Kebbi), Zone-II, (Argungu), Zone III (Suru) and Zone IV (Yauri), with human population of 3, 630, 9313 and total area of 36,229 square kilometres [9]. Various water bodies, for example, River Niger, Rima and River Ka are sources of water for the water system, residential use and fishing. Most of the people are occupied in arable cultivating, animal raising and nourishment crop preparing [9].

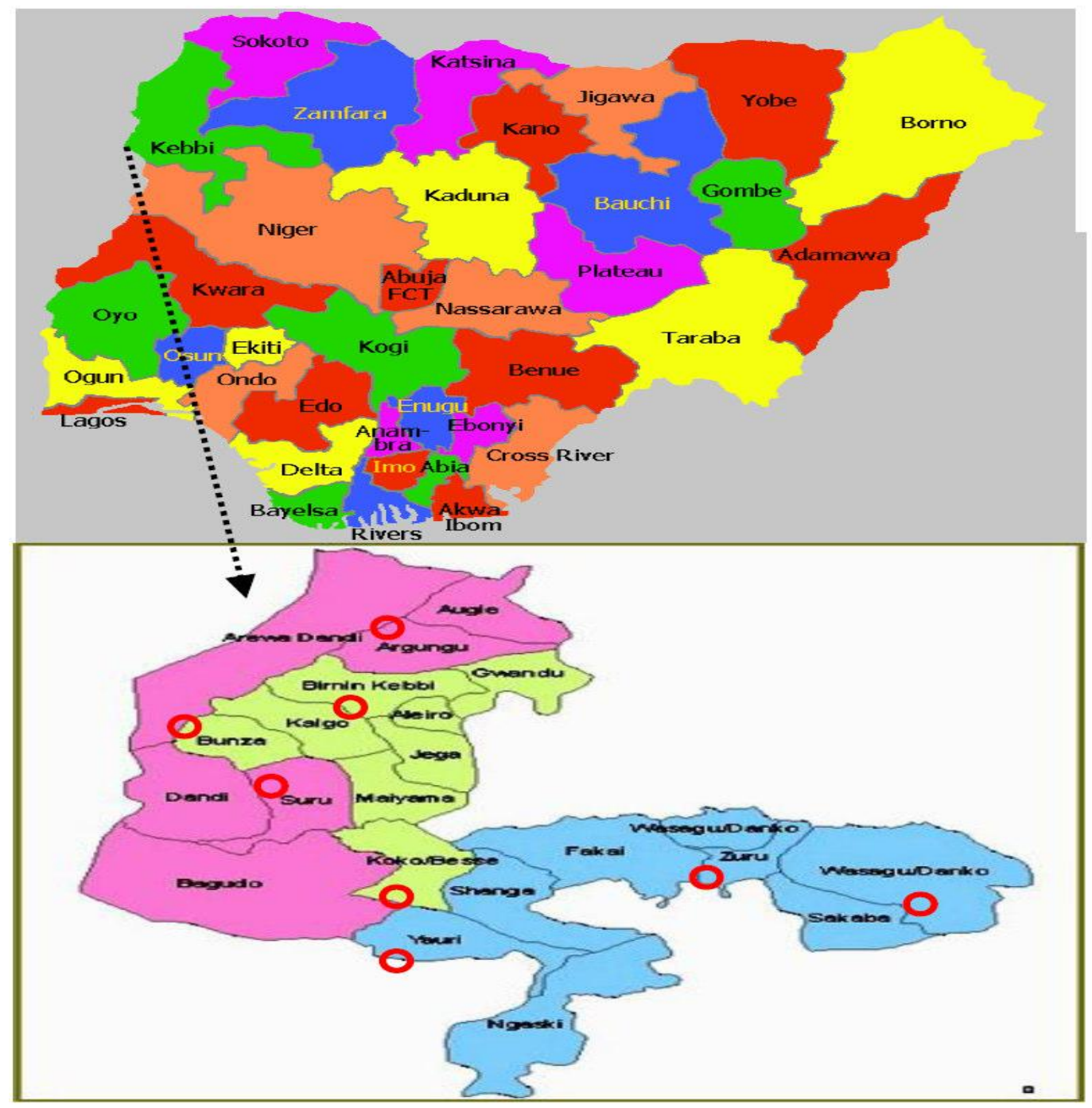




\subsection{Data and Sampling Method}

Figure 1: Map of Nigeria and Kebbi State

The study utilized a structured questionnaire to obtain primary data from a field survey carried out during the 2016 production season. Following [10], 398 respondents were calculated at $95 \%$ confidence interval as the representative of 20012 rice farmers' population in the investigation area. Simple random sampling relative to the population of each zone was followed to obtain the sample for each zone (Table 1).

Table 1. Sample design outlay for the investigation

\begin{tabular}{|c|c|c|}
\hline Zone & Population & Sample \\
\hline Birnin Kebbi & 20833 & 118 \\
\hline Argungu & 13436 & 76 \\
\hline Suru & 28657 & 163 \\
\hline Yauri & 7086 & 41 \\
\hline Total & $\mathbf{7 0 0 1 2}$ & $\mathbf{3 9 8}$ \\
\hline
\end{tabular}

Source: Field survey data, 2016

\subsection{Theoretical Framework}

The commonly used technique of efficiency breakdown is the Stochastic Frontier Production Function autonomously formulated by [11] and [12]. However, this traditional technique has an element that may genuinely limit its possibilities to depict generation innovation fittingly. The major drawback of the model is the understood presumption that if any input has a supportive outcome on yield, then a supportive outcome on yield fluctuation is additionally forced. This may not be correct because the effects of input on yield ought not to be attached from the earlier with the effects of input on yield variability [8]. A progressively wide random detailed model that joins two common functions; one shows the effects of input on mean yield and another looks at the effects of input on the variance yield was proposed by [8]. The model was detailed as:

$Y_{i}=f\left(X_{i}: \alpha\right)+g\left(Z_{i}: \Psi\right) v_{i}$

Where $f\left(X_{i}: \alpha\right)$ stand for the mean production function and $g\left(Z_{i}: \Psi\right)$ stand for the random component which shows the connection between the dimension of input and variance of the end product, $\alpha$ and $\Psi$ are the mean production function and the variance generation procedure parameters and $v_{i}$ is the stochastic term presumed to be iidN $(0,1)$. The factor $\mathrm{Z}$ isutilized to give details of end product difference and can be the same as input variable X. Thus, an input ${ }^{{ }_{i}}$ has different influence both on anticipated end product dimension, and end product difference since for this situation, the anticipated end product is acknowledged as: $E\left(Y_{i}\right)=f\left(X_{i}: \alpha\right)$ and the variance by $V\left(Y_{i}\right)=g^{2}\left(Z_{i}: \Psi\right)$. Appropriately, the effects of input vehave been isolated into two effects: the effects on average yield and the effects on average yield variation. The marginal effect of an input $X_{i}$ that is the partial derivative of the variance concerning this input can, be positive ( risk increasing input), negative (risk decreasing input) or zero (risk-neutral input)[8]. This idea was altered by [13] and [14] prompting SFA with adaptable risk stipulation. The method of breakdown suggested for this investigation is consonant with [14]. The model details as:

$Y_{i}=f\left(X_{i}: \alpha\right)+g\left(Z_{i}: \Psi\right) v_{i}-\left(W_{i}: \delta\right) u_{i}$

$Y_{i}$ relate to the watched output make by i-th farm, $f\left(X_{i}: \alpha\right)$ is the deterministic output procedure, $g\left(Z_{i}: \Psi\right)$ is the output risk procedure, $\Psi$ are to be calculated coefficients of the generation risk procedure, ${ }^{X_{i}}$ are the input factors, $\alpha$ are to be calculated coefficients of the mean output procedure, $g\left(W_{i}: \delta\right)$ stand for the technical inefficiency model, $\delta$ are to be calculated parameters in the technical inefficiency model, $v_{i}$ is the stochastic risk standing for generation risk and $u_{i}$ stand for farm unique technical inefficiencies. Taking into account the estimations of the factors, the unskillfulness resulting from a lack of efficiency affects $u_{i}$ the average yield of $i$-th person who grows rice is presented as:

$E\left(Y_{i} / X_{i}, U_{i}\right)=f\left(x_{i}: \alpha\right)-g\left(x_{i}: \Psi\right) u_{i}$

The technical efficiency is given by formula (4) which is steady with [14] stipulation of technical efficiency. 
$T E_{i}=\frac{E\left(Y_{i} / X_{i}, U_{i}\right)}{E\left(Y_{i} / X_{i}, U_{i}=0\right)}=\frac{f\left(x_{i}: \alpha\right)-g\left(x_{i}: \Psi\right) u_{i}}{f\left(x_{i}: \alpha\right)}=1-\frac{u g\left(x_{i}: \Psi\right)}{f\left(x_{i}: \alpha\right)}$

Technical inefficiency (TI) is presented as:

$T I_{i}=\frac{u g\left(x_{i}: \Psi\right)}{f\left(x_{i}: \alpha\right)}$

Technical efficiency therefore becomes;

$T E_{i}=1-T I_{i}$

Given the presumption of irregular errors, a log probability function for the watched farm output is parameterized in terms of

$\delta^{2}=\delta_{v}^{2}+\delta_{u \text { and }}^{2} \lambda=\delta_{u}^{2} / \delta_{v}^{2} \geq 0$

\subsection{Observational Model Specification}

The practical use of this investigation is steady with structures formulated by $[8,11,12,14]$. The deterministic component of the generation frontier in formula (2) presumed a trans-log model in formula (7)

$\operatorname{Ln} Y_{j}=\alpha_{0}+\sum_{i=1}^{4} \alpha_{i} \operatorname{Lnx} x_{j i}+0.5 \sum_{j=1}^{4} \sum_{k=1}^{4} \alpha_{j k} \operatorname{Lnx} x_{j i} \operatorname{Ln} k i$

Where $Y_{j}$ stand for a yield of farmer $\mathrm{j},{ }^{x_{i i}}$ is the amount of $\mathrm{j}^{\text {th }}$ input ${ }^{x_{i},} \alpha_{0}$ and $\alpha_{j}$ are the unknown parameters to be estimated and $\varepsilon_{i}$ is the composite error term. The error term is further given as:

$\varepsilon_{i}=g\left(x_{i}: \Psi\right) v_{i}-q\left(w_{i}: \delta\right) u_{i}$

Where $g(x: \Psi) v_{i}$ is the risk function component, $q(w: \delta) u_{i}$ is the technical inefficiency component, $\Psi$ and $\delta$ are the risk and technical inefficiency parameters to be estimated, $v_{i}$ catches the effects of measurement error and $u_{i}$ captures the inefficiency effects. The additive generation risk procedure is presented as:

$g\left(x_{i}: \Psi\right)=\Psi_{0}+\sum_{m=1}^{4} \Psi_{m} x_{m i}$

Where $x_{m}{ }^{\prime} s$ capture the input factors as depicted in Table $1, \Psi_{m}{ }^{\prime} s$ are the unknown coefficients of risk function parameters. If $\Psi_{m}{ }^{\prime} s$ it becomes negative, the particular factor decreases output variance otherwise increases [8]. The technical inefficiency effects can be demonstrated as:

$g\left(w_{i}: \delta\right)=\delta_{0}+\sum_{j=1}^{6} \delta_{j} w_{i j}$

Where $\delta_{j}{ }^{\prime} s$ stand for the unidentified parameter estimates of technical inefficiency model and $w_{j}{ }^{\prime} s$ are the input factors. 


\subsection{RESULTS AND DISCUSSION}

\subsection{Depiction of Variables and Summary Statistics}

Table 2 depicts the variables used in the investigation and summary statistics. It shows the average farm size of 1.7 hectares with a standard deviation of 0.48 hectares. This entails that rice cultivating in the investigation region is on a small scale basis. The small farm size may constrain the quantity of output. The mean age of 51 years and average family size of 8 persons per household shows that the respondents are still young with large family size. The large family size could be attributed to the polygamous practice in the area. Thus, the availability of young farmers and large family size in the investigation region implies cheap family labour if the household could use their family, which may reduce the costs of labour. On average, the respondents level of education ranges from vocational to polytechnic; however, some reasonable number of farmers are above or below the average as indicated by the coefficient of 1.54. The mean farming experience of 15.8 years with average extension contact of about 5 times per production season shows that the farmers have the required experience and augmentation services to manage their farm business. The depiction of the inefficiency variables agrees with the findings of [15, 16 and 17].

The statistics for output and input factors from Table 2 shows the average production of the surveyed homesteads was 4120 $\mathrm{kg} / \mathrm{ha}$ with a standard deviation of $522.9 \mathrm{~kg} / \mathrm{ha}$. This implies a large variability among the sampled farms in the investigation region. The average amount of seed used was $114.4 \mathrm{~kg} / \mathrm{ha}$ with the variability of $13.6 \mathrm{~kg} / \mathrm{ha}$. On average, the respondents used $170.1 \mathrm{~kg} / \mathrm{ha}$ of fertilizer with about $59 \mathrm{~kg} / \mathrm{ha}$ mean difference. This entails a large variation of its use among the surveyed farms. The normal use of agrochemical was 2.2 litres per hectare with least (1.01) coefficient of variation among all the inputs used. On normal ground, a respondent spent 36 man-days to cultivate 1 hectare; however, the variability of the mean stood at 10 man-days per hectare. The output-input variables of this investigation agrees with the findings of [15 and 18].

Table 2: Variable depiction and summary statistics

\begin{tabular}{|c|c|c|}
\hline Output and Input Factors & Depiction & Mean (Std. Dev.) \\
\hline$y_{1 i}$ & Rice grains (Kg/ha) & $4120.8(522.9)$ \\
\hline$x_{1 i}$ & Seed (Kg/ha) & $114.4(13.6)$ \\
\hline$x_{2 i}$ & Fertilizer (Kg/ha) & $170.1(58.7)$ \\
\hline$x_{3 i}$ & Agrochemicals (lt/ha) & $2.2(1.01)$ \\
\hline$x_{4 i}$ & Labour (Man-day/ha) & $36.3(10.1)$ \\
\hline$w_{1 i}$ & & $1.7(0.48)$ \\
\hline$w_{2 i}$ & Farm size (Hectares) & $51.0(6.89)$ \\
\hline$w_{3 i}$ & Age (Years) & $8.0(4.2)$ \\
\hline$w_{4 i}$ & Family size (Number) & $2.2(1.54)$ \\
\hline$w_{5 i}$ & Education level (Ranked) & $15.8(6.1)$ \\
\hline$w_{6 i}$ & Farming experience (Years) & $4.3(1.6)$ \\
\hline
\end{tabular}

Source: Field survey data, 2016. Note: Std. Dev. Standard Deviation

Output and input factors have been standardized by their individual means. Man days for work have been determined with the formula in accordance with [19] one adult man (greater or equivalent to 18 years) laboring for 8 hours equivalent to 1 man-day, adult woman labouring for 8 hours equivalent to 0.75 man-days and a child (less than 18 years) labouring for 8 hours is equivalent to 0.5 man-day.

In the inefficiency factors, positioning the dimension of formal schooling for the investigation follows [20].

\subsection{Maximum Likelihood Estimates of Trans-log Stochastic Frontier Production}

Table 3 presents the maximum likelihood estimates of the trans-log stochastic production function. The presumption that there is no wastefulness and production risk in input use $(\lambda=0)$ was substantially rejected at $1 \%$ level of significance ( $\lambda$ $=2.1414$ ). Technical inefficiency and production risk in input use contribute significantly to yield variability. Also, we find that $82.1 \%$ variation in the observed yield is caused by technical inefficiency $(\gamma=0.8209)$. This investigation agrees with $[21$ and $15]$.

Table 3. Maximum likelihood estimates of the trans-log stochastic frontier Production model

\begin{tabular}{|c|c|c|c|}
\hline Variable & Parameter & Coefficient & Standard Error \\
\hline Constant & $\alpha_{0}$ & $-3.2004^{*}$ & 1.7516 \\
\hline Lnseed & $\alpha_{1}$ & $0.6611^{* * *}$ & 0.2995 \\
\hline
\end{tabular}




\begin{tabular}{|c|c|c|c|}
\hline Lnfertilizer & $\alpha_{2}$ & $3.3174^{* * * *}$ & 1.1929 \\
\hline Lnagrochemicals & $\alpha_{3}$ & $0.9522^{* *}$ & 0.4829 \\
\hline Lnlabour & $\alpha_{4}$ & $-2.8772^{* * * *}$ & 0.3948 \\
\hline $0.5 \operatorname{Ln}(\text { Seed })^{2}$ & $\alpha_{11}$ & $0.2185^{* * *}$ & 0.0394 \\
\hline $0.5 \operatorname{Ln}(\text { Fertilizer })^{2}$ & $\alpha_{22}$ & $3.6599^{* * * *}$ & 1.3201 \\
\hline $0.5 \operatorname{Ln}(\text { Agrochemical })^{2}$ & $\alpha_{33}$ & $0.5086^{*}$ & 0.2881 \\
\hline $0.5 \operatorname{Ln}(\text { Labour })^{2}$ & $\alpha_{44}$ & 2.0696 & 1.5322 \\
\hline (Lnseed)(Lnfertilizer) & $\alpha_{12}$ & $1.1012^{* * * *}$ & 0.3014 \\
\hline (Lnseed)(Lnagrochemicals) & $\alpha_{13}$ & $0.6305^{* *}$ & 0.3201 \\
\hline (Lnseed)(Lnlabour) & $\alpha_{14}$ & -0.0558 & 0.2179 \\
\hline (Lnfertilizer) (Lnagrochemicals) & $\alpha_{23}$ & $2.1588^{* * *}$ & 1.0822 \\
\hline (Lnfertilizer)(Lnlabour) & $\alpha_{24}$ & $-3.0074^{* * * * 6}$ & 0.4817 \\
\hline (Lnagrochemicals)(Lnlabour) & $\alpha_{34}$ & $-2.3396^{*}$ & 1.4221 \\
\hline \multicolumn{4}{|l|}{ Variance Parameters } \\
\hline Sigma-square(u) & $\sigma_{\mathrm{u}}$ & $0.0424 * * *$ & 0.006 \\
\hline Sigma-square(v) & $\sigma_{\mathrm{v}}$ & $0.0198 * * *$ & 0.003 \\
\hline Sigma-square $\left({\sigma_{\mathrm{v}}}^{2}+\sigma_{\mathrm{u}}^{2}\right)$ & $\sigma^{2}$ & $0.0022 * * *$ & 0.0004 \\
\hline Lambda $\left(\delta_{u}^{2} / \delta_{v}^{2}\right)$ & $\lambda$ & $2.1414 * * *$ & 0.0091 \\
\hline $\operatorname{Gamma}\left(\lambda^{2} /\left(1+\lambda^{2}\right)\right.$ & $\gamma$ & 0.8209 & \\
\hline Sample size & $\mathbf{n}$ & 398 & \\
\hline
\end{tabular}

Source: Field survey data, 2016. Note: ${ }^{*}, \quad$ and ${ }^{* * * *}$ are $10 \%, 5 \%$ and $1 \%$ significances Levels

\subsection{Elasticity of Production}

The elasticity of output concerning each input used in trans-log stochastic frontier production function was determined following [22]. The output elasticities show a measure of the responsiveness of rice output to changes in the various input variables. A summation of the partial elasticities of various input variables concerning output is a measure of the returns to scale of the rice farms. A positive sign implies that as the variable input increase, rice output will increase and vice versa.

Table 4 presents the output elasticity for seed, fertilizer, agrochemicals, and labour as $0.3295,0.3341,0.1831$ and 0.2131 individually. The implication is that fertilizer has the highest contribution to rice output, followed by seed, labour and chemicals. It also implies that a $1 \%$ increase in seed per hectare, holding other factors constant will increase rice output by $0.3295 \%$. Similar interpretation applied to fertilizer, agrochemicals and labour. The rate of returns to scale was 1.0598; this infers that when all inputs are jointly increased by $1 \%$, rice output will increment by $1.059 \%$. The result agrees with [23 and 15]

Table 4: Elasticity of production and returns to scale

\begin{tabular}{|c|c|}
\hline Variable & Elasticities \\
\hline Seed & 0.3295 \\
\hline Fertilizer & 0.3341 \\
\hline Agrochemicals & 0.1831 \\
\hline Labour & 0.2131 \\
\hline Return to Scale (RTS) & $\mathbf{1 . 0 5 9 8}$ \\
\hline
\end{tabular}

Source: Field survey data, 2016

\subsection{Maximum Likelihood Estimates of Production Risk Function}

Table 5 presents the maximum likelihood estimates of the production risk function. We find that fertilizer and labor are factors that substantially reduce yield variability while seed and agrochemicals are risks increasing factor though not strong. This result agrees with [24 and 15].

Table 5 Maximum likelihood estimates of production risk

\begin{tabular}{|c|c|c|c|}
\hline Variable & Parameters & Estimates & Standard Error \\
\hline Constant & $\Psi_{0}$ & $-1.1012^{* * *}$ & 0.3014 \\
\hline Lnseed & $\Psi_{1}$ & 0.1862 & 0.1952 \\
\hline Lnfertilizer & $\Psi_{2}$ & $-0.3468^{* *}$ & 0.1774 \\
\hline Lnagrochemicals & $\Psi_{3}$ & 0.0547 & 0.0670 \\
\hline Lnlabour & $\Psi_{4}$ & $-0.3425^{*}$ & 0.1878 \\
\hline
\end{tabular}

Source: Field survey data, 2016: Note: ${ }^{* * * *}$ and ${ }^{* * * *}$ denotes $10 \%, 5 \%$ and $1 \%$ Significance levels 


\subsection{Technical Efficiency Estimates}

Rice generation in the investigation territory is defined by unskillfulness coming from a lack of efficiency. The minimum and maximum efficiency scores stood at 0.161 and 0.978 accordingly (Table 6). The average technical efficiency score of 0.821 , implying that the farmers are $17.9 \%$ below the maximum end product. Thus, there is room to expand yield by $17.9 \%$ simply by adopting the technology of the best practices of the best farm. The result agrees with [25 and 15].

Table 6: Technical efficiency distribution of the respondents' trans-log model

\begin{tabular}{|c|c|c|}
\hline Efficiency Scores & Frequency & Percentage \\
\hline 1.00 & 0 & 0.00 \\
\hline$>0.90<1$ & 130 & 32.7 \\
\hline$>0.80 \leq 0.90$ & 127 & 31.9 \\
\hline$>0.70 \leq 0.80$ & 51 & 12.8 \\
\hline$>0.60 \leq 0.70$ & 36 & 9.1 \\
\hline$>0.50 \leq 0.60$ & 32 & 8.0 \\
\hline$>0.10 \leq 0.50$ & 22 & 5.5 \\
\hline Total & $\mathbf{3 9 8}$ & $\mathbf{1 0 0}$ \\
\hline Mean & 0.821 & \\
\hline Minimum & 0.161 & \\
\hline Maximum & 0.978 & \\
\hline Standard Deviation & 0.152 & \\
\hline
\end{tabular}

Source: Field survey data, 2016

\subsection{Estimates of Technical Inefficiency}

Table 6. Presents maximum likelihood estimates of technical inefficiency model. The result shows extension contact and education level are factors significantly decreasing the technical inefficiency of the respondents while the household size is increasing their technical inefficiency substantially. The result of household increasing technical inefficiency agrees with [26] while education and extension contact decreasing technical inefficiency agrees with [27 and 28].

Table 6: Maximum likelihood estimates of technical inefficiency function

\begin{tabular}{|c|c|c|c|}
\hline Variables & Parameters & Estimates & Standard Error \\
\hline Constant & $\delta_{0}$ & $-3.4895^{* *}$ & 1.6121 \\
\hline Farm size & $\delta_{1}$ & 0.1862 & 0.1952 \\
\hline Age & $\delta_{2}$ & 1.0615 & 1.0859 \\
\hline Family size & $\delta_{3}$ & $2.8148^{*}$ & 1.6831 \\
\hline Education level & $\delta_{4}$ & $-0.4014^{*}$ & 0.2175 \\
\hline Farming experience & $\delta_{5}$ & 1.4796 & 1.5433 \\
\hline Extension contact & $\delta_{6}$ & $-0.4778^{* *}$ & 0.2048 \\
\hline
\end{tabular}

Source: Field survey data, 2016: Note: ${ }^{*}$ and ${ }^{* *}$ are $10 \%$ and $5 \%$ levels of significance

\subsection{CONCLUSIONS}

This study modeled technical efficiency with production risk using surveyed data of 398 farmers in Kebbi State. Estimates from a stochastic frontier structure with flexible risk stipulation proved that rice production in the investigation region is characterized by increasing returns to scale. Fertilizer and labour were found to be risk decreasing factors, while seed and agrochemicals are risk increasing inputs. On a normal, rice creation in the investigation zone has been, in fact, wasteful (0.821). The estimates of inefficiency function show education level and extension contact are significant factors decreasing technical inefficiency; however, household size was found to increase technical inefficiency substantially. The study advocates plan of action to encourage the effective and proper use of fertilizer and labour, extension services, increase access to education. Also, farmers should encourage the active participation of their family members. Finally, it is allowed to include generation risk in technical efficiency breakdown if the inputs are non-neutral in risk.

\section{ACKNOWLEDGMENTS}

Special acknowledgment goes to all authors for their contribution in conception, design, analysis and results in a discussion of the investigation. Also, the contribution of Rice Farmers Association in Kebbi State during data collection is highly appreciated.

\section{REFERENCE}

1. FMARD, 2016. Agricultural Promotion Policy 2016-2020: Building on the success of ATA, closing gaps, Federal Ministry of Agriculture and Rural Development, Nigeria. 
2. Ugalahi, U. B., Adeoye, S. O. and Agbonlahor, M. U., 2016. Irrigation Potentials and rice self- Sufficiency in Nigeria: A review. African Journal of Agricultural Research, 11(5), 298-309.

3. Evbuomwan, G.O. and Okoye, L.U.2017. Evalating the Prospects of the Anchor Borrowers'Programme for Small Scale Farmers in Nigeria. In: International Farm Management Congress, 2nd to 7th July 2017, Scotland United Kingdom. . Paper presented at the International Farm Management Congress.

4. Kara, H.A., Shamsudin, M.N., Muhamed, Z., Latif, I.B. and Seng, K.W.K. 2019. Estimation of technical efficiency for rice farms in Kebbi State: A Data Envelopment Analysis (DEA) Approach. IORS Journal of Agriculture and Veterinary Science (IOSR-JAVS), 12(5), 25-31.

5. Mojo, D., Fischer, C. and Degefa, T. 2017. The determinants and economic impacts of membership in coffee farmer cooperatives: recent evidence from rural Ethiopia. Journal of Rural Studies, 50, 84-94.

6. Asche, F. and Tveterås, R. 1999. Modelling production risk with a two-step procedure. Journal of Agricultural and Resource Economics, 424-439.

7. Antle, J. M. 1983. Testing the stochastic structure of production: a flexible moment-based approach. Journal of Business and Economic Statistics, 1(3), 192-201.

8. Just, R. E., and Pope, R. D. 1978. Stochastic specification of production functions and economic implications. Journal of econometrics, 7(1), 67-86.

9. Usman, S. 2016. Surface soil factors and soil characteristics in geo-physical milieu of Kebbi State Nigeria. Eurasian Journal of Soil Science, 5(3), 209-220.

10. Yamane, T. 1967. Problems to accompany" Statistics, an introductory analysis". Harper and Row.

11. Aigner, D. J., Lovell, C. A. K. and Schmidt, P. 1977. Formulation and estimation of stochastic frontier production function models. Journal of econometrics, 6(1), 21-37.

12. Meeusen, W. and van Den Broeck, J. (1977). Efficiency estimation from Cobb-Douglas production functions with composed error. International economic review, 435-444.

13. Battese, G. E., Rambaldi, A. N. and Wan, G. H. 1997. A stochastic frontier production function with flexible risk properties. Journal of Productivity Analysis, 8(3), 269-280.

14. Kumbhakar, S. C. 2002. Specification and estimation of production risk, risk preferences and technical efficiency. American Journal of Agricultural Economics, 84(1), 8-22.

15. Kara, A. H., Shamsudin, M. N., Mohamed, Z., Latif, I. B. and Seng, K. W. K. 2019. Technical Efficiency and Production Risk of Rice Farms under Anchor Borrowers Programme in Kebbi State, Nigeria. Asian Journal of Agricultural Extension, Economics and Sociology, 1-12.

16. Oranusi, S. and Dahunsi, S. O. 2015. Preliminary study on hazards and critical control points of kokoro, a Nigerian indigenous fermented maize snack. SpringerPlus, 4(1), 253.

17. Ogundari, K. 2014. The paradigm of agricultural efficiency and its implication on food security in Africa: what does metaanalysis reveal? World Development, 64, 690-702.

18. Villano, R., Bravo-Ureta, B., Solís, D. and Fleming, E. 2015. Modern rice technologies and productivity in The Philippines: disentangling technology from managerial gaps. Journal of Agricultural Economics, 66(1), 129-154.

19. Coelli, T. J. and Battese, G. E. 1996. Identification of factors which influence the technical inefficiency of Indian farmers. Australian Journal of Agricultural Economics, 40(2), 103-128.

20. Onumah, E. E. and Acquah, H. 2011. A stochastic production investigation of fish farms in Ghana. Agris on-line Papers in Economics and Informatics, 3(665-2016-44862), 55.

21. Abdul-Rahaman, A. and Abdulai, A. 2018. Do farmer groups impact on farm yield and efficiency of smallholder farmers? Evidence from rice farmers in northern Ghana. Food Policy, 81, 95-105. htt:// doi:10.1016/j.foodpol.2018.10.007.

22. Sharma, K. R. and Leung, P.1998. Technical efficiency of the long line fishery in Hawaii: an application of a stochastic production frontier. Marine Resource Economics, 13(4), 259-274.

23. Ali, A. and Jan, A. U. 2017. Analysis of technical efficiency of sugarcane crop in Khyber Pakhtunkhwa: a stochastic frontier approach. Sarhad Journal of Agriculture, 33(1), 69-79.

24. Oppong, B. A., Onumah, E. E. and Asuming-Brempong, S. 2016. Technical efficiency and production risk of maize production: evidence from Ghana. Asian J. Agric. Extens. Econ. Soc., 11(3), 1-9.

25. Shavgulidze, R., Bedoshvili, D. and Aurbacher, J. 2017. Technical efficiency of potato and dairy farming in mountainous Kazbegi district, Georgia. Annals of Agrarian Science, 15(1), 55-60.

26. Yusuf, S. and Malomo, O. 2007. Technical efficiency of poultry egg production in Ogun state: a data envelopment analysis (DEA) approach. International journal of poultry science, 6(9), 622-629.

27. Coelli, T.J., Rao, D.S.P., O’Donnell, C.J. and Battese, G.E. (2005). An introduction to efficiency and productivity analysis: Springer Science and Business Media.

28. Lemessa, S. D., Yismawu, M. A., Daksa, M. D. and Watabaji, M. D. 2017. Risk Adjusted Production Efficiency of Maize Farmers in Ethiopia: Implication for Improved Maize Varieties Adoption. Turkish Journal of Agriculture-Food Science and Technology, 5(9), 1099-1107. 